\title{
Implikasi Penyimpangan Gangguan Fethisme dalam Kesehatan Mental
}

\author{
Ulin Nihayah ${ }^{1}$, Riza Umami ${ }^{2}$, Lutfi Kharisma N.A ${ }^{3}$, Nabila Anis Saputri ${ }^{4}$ \\ 12,3,4, UIN Walisongo Semarang \\ *Corresponding author, e-mail: nabilaanisa180@gmail.com
}

\begin{abstract}
A fetish case is a case in which the perpetrator has sexual aberrations with body parts or an object (called a fetish) in order to get sexual stimulation and satisfaction. The perpetrator will be stimulated on a body part or an object which for some people is just a stimulus. The object will make the basis of fantasy and help romance but is not a substitute for more conventional sexual activities, fetishes that may be on body parts such as the buttocks of the eyes while on inanimate objects such as cloth, underwear, shoes, etc. this fetish is a form of sexual crossing which, if carried out continuously, can result in on going stress and dismpt the mental health of the perpetrator. The research method used in writing this journal is descriptive qualitative which is used to examine natural objects, by untilizing qualitative data and then sharing descriptively. The results of the analysis show that fetish behavior can affect mental health and can be cured by treatment in the form of sex education and Islamic therapy. Sex education is given, among others, about the ethics of asking permission to look at things, avoiding and various forms of sexual stimulation, provide lessons on how to protect yourself from despicable acts if you are not married, provide understanding and counseling related to the dangers of adultery. Meanwbile, Islamic therapy includes submission in prayer, but suggestions for self-introduction and self- authoritarian acts.
\end{abstract}

Keyword: Sexual deviance, Fetish, Mental Health.

\section{Pendahuluan}

Penyimpangan seksual adalah permasalahan yang menjadi problem sosial di masyarakat. Permasalahan penyimpangan seksual yang dialami oleh beberapa korban seringkali tidak melakukan pelaporan ataupun pembelaan serta menganggap penyimpangan seksual menjadi sesuatu yang biasa dan wajar terjadi. Bahkan sering ditutup-tutupi oleh pelakunya. Perilaku penyimpangan seksual banyak diberitakan pada media massa, seperti media cetak, elektronik, yang meresahkan masyarakat.

Mengenai penyimpangan seksual sebagaimana kasus yang terjadi pada tahun 2021 yang dilakukan oleh oknum dokter yang mencampurkan spermanya dimakanan istri temannya di Semarang Jawa Tengah. Hal ini dinilai Komnas Perempuan sebagai golongan pelecehan seksual non-fisik dalam bentuk mengintip korban (detik.com, 2021). Kasus lainnya adalah penyimpangan seksual yang dilakukan oleh penyanyi dangdut berinisial SJ pada tahun 2016 kepada anak laki-laki dibawah umur. Dimana SJ melakukan tindakan yang tidak senonoh kepada korban yang akhirnya pelaku dihukum 8 tahun penjara. Ada juga kasus yang viral pada tahun 2020 tentang kain jarik. Dimana seorang mahasiswa berinisial G seorang mahasiswa semester akhir di perguruan tinggi di Surabaya yang menjadikan 25 juniornya sebagai objek seksualnya. Tindakannya dilakukan di media sosial, para korbannya diminta untuk membungkus dirinya dengan kain jarik serta direkatkan dengan lakban hitam. Tindakannya ini pertama kali dibongkar oleh seorang pengguna twitter yang 
menjadi salah satu korban dari G (suara.com, 2021). Selanjutnya kasus yang terjadi pada sekitar tahun 2011, kasus penyimpangan seksual terungkap, dengan munculnya kausu terkait sodomi yang dilakukan terhadap anak jalanan serta pelaku bahkan telah dilakukan dikenakan jeratan hukum. Selain itu juga muncul kasus penyimpangan seksual terkait orientasi mencuci pakaian dalam perempuan yang terjadi di tahun 2014. Dimana pelaku berdalih dengan ilmu hitam. Kasus yang lain terkait deviasi seksual terjadi juga pada tahun 2015 dimana sang pelaku tidak hanya mencuri pakaian dalam tetapi hingga melukai alat vital objeknya (Sukoco, et. Al, 2021).

Beberapa kasus yang terjadi tersebut bukan merupakan hal yang sepele dan terjadi secara tiba-tiba tetapi ada kaitannya dengan adanya gangguan mental yang dimiliki oleh pelaku penyimpangan seksual. Perilaku penyimpangan seksual yang terjadi dimasyarakat, memiliki dampak tersendiri bagi korbannya terutama dampak psikologis korban penyimpangan seksual. Salah satu perilaku penyimpangan seksual yang akan kita bahas ini adalah yang terjadi pada kasus fetish.

Fetishisme adalah bentuk penyimpangan seksual dengan menggunakan benda seks seperti pakaian dalam, sepatu, kaos kaki, atau lainnya guna mencapai kepuasan seksualnya (Hidayat \& Uliyah, 2015). Orang dengan paraphilia fetish (fetishisme) terkuasai oleh suatu objek dan menjadi ketergantungan pada objek ini untuk mencapai kepuasan seksual, orang tersebut lebih menyukai hal tersebut daripada mempunyai intimasi seksual dengan pasangan (Syafi'I, 2014). Adapun gejala khusus fetish antara lain adalah memiliki fantasi seksual secara berulang atau intens, mempunyai dorongan seksual atau sikap yang melibatkan penggunaan benda mati selama setidaknya enam bulan juga memiliki fantasi, dorongan seksual, atau perilaku yang menyebabkan tekanan yang signifikan klinis atau penurunan fungsi sosial, pekerjaan, ataupun fungsi lainnya. Gejala lainnya adalah ketidak mampuan membangun relasi sosial, dan juga cinta yang mendalam (Syafi'i, 2014). Penyimpangan seksual dalam bentuk Fetish ini berkaitan dengan kesehatan mental pelakunya. Menurut Darajat, kesehatan mental adalah keharmonisan dalam kehidupan yang terwujud antara fungsi-fungsi jiwa, kemampuan dalam menghadapi problematika yang dihadapi, serta bisa merasakan kebahagiaan serta kemampuan dirinya secara positif. Beliau juga menekankan bahwa kesehatan mental adalah kondisi dimana individu terhindar dari gejala gangguan jiwa (neurose) dan dari gejala penyakit jiwa (psychose).

Seseorang yang sehat mental adalah orang-orang yang dalam ruhaninya atau dalam hatinya selalu merasa tenang, tentram dan juga aman. WHO mendefinisikan tentang kesehatan mental sebagai kondisi kesejahteraan inividu yang menyadari potensinya sendiri, bisa mengatasi tekanan kehidupan yang normal, bisa bekerja dengan produktif dan berbuah, serta mampu memberi kontribusi kepada komunitasnya. Kesehatan mental merujuk pada bagaimana individu mampu menyesuaikan diri dan juga berinteraksi baik dengan lingkungan sekitarnya, sehingga individu terhindar dari gangguan mental. Karakteristik kesehatan mental bisa dilihat dai ciri-ciri mental yang sehat, cirinya yaitu terhindar dari gangguan jiwa, mampu menyesuaikan diri, mampu memanfaatkan potensi dengan maksimal, mampu mencapai kebahagiaan pribadi dan orang lain (Fakhriyani, 2017).

Gangguan mental merupakan pola psikologi atau sikap yang pada umumnya terkait dengan stress atau kelainan mental yang tidak dianggap sebagai bagian dari perkembangan manusia secara normal. Dalam Diagnostic and Statistical Manual of Mental Disorder 5 (DSM-V) diterangkan bahwa penyakit mental yang terkait dengan stress adalah parafilia atau suatu bentuk penyimpangan objek terhadap ketertarikan seksual, salah satunya adalah fetishisme. Gangguan parafilia ini 
dikonseotualisasikan sebagai gangguan yang menyebabkan tekanan individu yang menyebabkan kerugian bagi individu maupun orang lain (Fatima, 2019).

Perilaku fetish tidak hanya merugikan korban dari pelaku namun juga turut meresahkan masyarakat yang memberikan stigma negative oleh pelaku penyimpangan seksual. Nafsu fetish yang berkelanjutan jika tidak dihentikan dan ditangani bukan hanya membahayakan korban itu sendiri melainkan juga orang-orang yang berada disekitar pelaku. Oleh karenanya sangat penting bagi bagi penulis untuk membahas terkait dengan deviasi seksual dan juga terapi penanganan yang bisa digunakan untuk menghentikan perilaku fetish dan juga meminimalisir bentuk penyimpangan seksual berupa fetish. Metode kualitatif deskriptif ini mengarah pada objek yang alamiah serta memanfaatkan data kualitatif kemudian dijabarkan secara deskriptif. Terkait kasus-kasus deviasi seksual berupa fetish, kesehatan mental, dan terapi keislaman

\section{Metode}

Metode penelitian yang digunakan dalam penulisan ini secara menyeluruh adalah menerapkan metode kualitatif deskriptif. Penelitian kualitatif banyak digunakan dalam penelitian di bidang social (Anggit \& Setiawan, 2018). Penelitian deskriptif bertujuan guna mengungkapkan berbagai informasi kualitatif dengan pendeskripsian secara teliti dan penuh dengan nuansa untuk menggambarkan secara cermat suatu hal serta fenomena, dan juga tidak terbatas pada pengumpulan data saja, tetapi meliputi analisis dan interpretasi. Penelitian kualitatif mempunyai karakteristik datanya dinyatakan dalam keadaan yang sewajarnya, senyatanya dan tidak mengubah dalam bentuk simbol-simbol berupa bilangan (Setyamuko \& Supriyanto, 2017). Metode penelitian ini sudah menjadi metode yang sangat umum guna melakukan penelitian di berbagai disiplin ilmu, termasuk pendidikan, psikologi, ilmu sosial, dan lain sebagainya. Metode deskriptif ini pada dasarnya berusaha untuk menggambarkan serta menjelaskan mengenai suatu gejala sosial. Metode kualitatif memberikan informasi yang mutakhir sehingga bisa bermanfaat untuk perkembangan ilmu pengetahuan serta lebih banyak bisa diterapkan pada berbagai masalah dengan ungkapan lain tujuan dari metode kualitatif deskriptif ini ialah untuk memberikan kajian yang komprehensif serta spesifik yang berkaitan dengan fenomena atau kejadian yang terjadi dalam kehidupan sehari-hari ataupun dari peristiwa spesifik yang dialami oleh individu atau kelompok (Wardhani \& Krisnani, 2020).

\section{Hasil dan Diskusi}

Bentuk penyimpangan seksual merupakan segala macam aktivitas seksual yang ditempuh seseorang untuk mendapatkan kenikmatan seksual namun dengan cara yang tidak sewajarnya. Biasanya cara yang digunakan ialah dengan menggunakan objek seks yang tidak wajar. Perilaku penyimpangan seksual ini merupakan tingkah laku seksual yang bertentangan dan tidak dapat diterima dikalangan masyarakat karena tidak sesuai dengan norma agama dan norma tingkah laku seksual yang berkembang dimasyarakat. Penyebab terjadinya penyimpangan ini bersifat psikologis atau kejiwaan, seperti pengalaman sewaktu kecil dan traumatis, kemudian juga bisa dari lingkungan pergaulan dan adanya proses belajar sosial, selanjutnya dari faktor genetik seperti wanita yang memiliki hormon laki-laki lebih dominan dari hormon wanita dan sebaliknya. 
Menurut Kartono ketidakwajaran seksual "sexual perversion" ialah hal yang mencakup perilaku seksual atau fantasi-fantasi seksual yang diarahkan pada pencapaian orgasme lewat relasi diluar hubungan kelamin heteroseksual, yaitu dengan hubungan jenis kelamin yang sama atau dengan patner seks yang belum dewasa. Hal tersebut bertentangan dengan norma-norma tingkah laku seksual dalam masyarakat secara umum (Abidin \& Luthfi, 2016). Penyimpangan seksual bisa dibedakan dalam 4 macam Pertama, Menyimpang karena partnernya. Hubungan seks pada umumnya dilakukan dengan pasangan suami istri yang sudah menikah. Namun, pada saat ini banyak dijumpai manusia yang melakukan hubungan seks dengan suami atau istri orang lain (zina mubson) atau dengan orang yang belum menjadi suami atau istrinya (zina ghoiru muhson). Atau dengan orang yang punya hubungan dengan keluarga yang cukup dekat secara biologis yang tidak boleh untuk dinikahi (Inses), atau dengan sesama jenis (Homoseksual, lesbian), ataupun dengan binatang (Bestialitas), atau dengan anak kecil (Pedophilia), atau dengan mayat (Nekrofilia), atau dengan benda-benda miliki lawan jenis (Fetishisme). Kedua, menyimpang karena caranya. Dimana hubungan seks semestinya dilakukan dengan cara lazim atau semestinya. Tetapi ada orang yang memuaskan nafsu seksualnya dengan cara onani atau masturbasi, anal seks, oral seks, sodomi, sadisme, masokisme, transvestitisme, voyeurism, atau eksibisionisme. Ketiga, menyimpang karena partner dan caranya. Contohnya seperti sodomi, seks anal yang kemudian dilakukan terhadap sesame jenis (pada orang gay), maupun anakanak (pada orang pedophilia). Contoh lainnya adalah hubungan para lesbi yang dilaksanakan menggunakan alat bantu. Keempat, menyimpang karena kondisi pasangannya, contohnya seperti hubungan seks dengan istri yang dalam keadaan haid (Junaedi, 2016).

Dalam sumber yang lain dijelaskan mengenai macam-macam penyimpangan seksual diantaranya sebagai berikut: Pemerkosaan, Homoseksual, Lesbianisme (lesbi), Pedofilia (pedofil), Transvetisme, Sodomi, Masturbasi, Ekshibionisme, Voyeurisme, Incest, Sadisme, Nekrofilia, Troilisme, Bestialita (Abidin, 2016), Fetishisme (Annur, 2012), Zoophilia (Martasari, 2019), Masokhisme (Junaedi, 2016). Berdasarkan dari banyaknya jenis deviasi seksual tersebut, bisa saja pada seseorang mungkin terdapat penyimpangan seksual yang majemuk, sekalipun dari deviasi seksual tersebut ada yang dominan. Misalnya saja seperti gejala fetishisme yang dibarengi dengan masturbasi maupun ekshibisionisme. Lalu pada penderita homoseksual yang juga memiliki deviasi seksual sodomi juga (Alimi, 2004).

\section{Konsep Fetishisme (Fetish)}

Berasal dari bahasa Portugis feitico, yang berarti sulapan atau sihir. Kata ini mempunyai makna bahwa adanya ketergantungan seseorang pada suatu bagian tubuh maupun benda mati sebagai cara untuk mendapatkan gairah seksual maupun ejakulasi. Dengan kata lain, fetishme merupakan suatu keadaan dimana seseorang memiliki ketertarikan tertentu yang mengarah pada kepuasan seksual seseorang tehadap suatu objek tertentu seperti benda mati ataupun bagian tubuh tertentu. Dan keadaan ini biasanya lebih banyak ditemukan pada pria dibanding wanita.

Objek tersebut dapat berupa suatu bagian dari tubuh seorang wanita, seperti rambut kepala, rambut kemaluan, kuku, dll. Selain itu pada benda lainnya seperti pakaian, celana dalam, bra, syal dan yang lainnya (Abidin, 2016). Objek atau benda tersebut biasanya dikagumi secara berlebihan. Yang perlu digaris bawahi bahwa eksistensi maupun kepuasan seksual yang dirasakan oleh penderita dapat berbeda, namun biasanya berkisar pada melihat, mencium, meraba, memainkan, 
atau mengecup benda-benda tersebut. Selain itu biasanya diakhiri dengan perilaku masturbasi (Annur, 2021).

Perilaku fetishme ini merupakan termasuk dalam salah satu penyimpangan seksual. Hal tersebut karena adanya ketidakwajaran seksual pada seseorang, seperti pada perilaku dan fantasifantasi seksual yang diarahkan pada orgasme bukan melalui relasi dari hubungan kelamin. Selain itu, juga bertentangan dengan norma tingkah laku seksual yang ada pada masyarakat pada umumnya (Junaedi, 2016). Penyebab fetishme antara lain karena adanya perasaan infantil yang dibarengi dengan rasa yang agresif. Hal tersebut sering kali akibat dari sifat asosial dan dibayangi kecemasankecemasan tertentu seperti menjadi impoten. Sehingga benda-benda tersebut dibutuhkan untuk membangkitkan nafsu seksualnya (Abidin, 2016). Selain itu, penyebab lain dari perilaku fetishme ialah dari kurangnya kemampuan diri untuk menyesuaikan diri terhadap lingkungan pergaulan yang lebih luas. Hal tersebut biasanya karena faktor kecenderungan individu hanya tertarik dengan hal-hal tertentu saja membuat penderitanya mengalami kesulitan untuk bersosialisasi dengan lingkungan sekitarnya (Abidin, 2016).

Terdapat beberapa tingkatan pada penderita fetishme berdasarkan tindakan maupun hasrat terhadap objeknya, diantaranya yaitu:

1. Pemuja (admire)

Tingkatan pertama pada perilaku fetish disini masih bisa dikatakan wajar. Hal tersebut karena sifatnya hanya berupa suatu keinginan sesaat. Misalnya pada pria yang berkeinginan untuk mempunyai istri yang memiliki tubuh yang seksi dengan pantat yang besar, namun apabila hal tersebut tidak tercapai pria tersebut tidak masalah.

2. Pecandu (addict)

Pada tingkat kedua, penderita fetish sudah memasuki pada tahap ketergantungan terhadap objek tertentu yang menjadi kegemarannya. Apabila hasratnya kepada objek tersebut tidak terpenuhi, maka hal tersebut bisa menimbulkan gangguan pada kejiwaan.

3. Fetisisme tingkat menengah

Pada tingkat yang ketiga ini bisa dikatakan tahap yang berbahaya. Karena pada tingkat ini seorang penderita fetish akan nekat melakukan apa saja demi memenuhi keinginannya. Hal tersebut bisa berupa pencurian barang, penculikan, dan pemaksaan tertentu untuk mendapatkan objek yang diinginkan.

4. Fetisisme tingkat tinggi

Pada tingkat yang keempat ini, seorang penderita fetish tidak akan menghiraukan hal lain diluar fetishnya.

\section{Fetishistic murderers}

Tingkatan kelima ini merupakan tingkatan tertinggi pada fetishme. Seorang pendrita fetish pada tingkat ini akan tega membunuh bahkan memutilasi korbannya hanya untuk mengambil objek fetish yang diinginkannya (Junaedi, 2016). 


\section{Studi Kasus}

Belakangan ini istilah fetish ramai diperbincangkan kembali setelah munculnya kasus-kasus fetish yang beredar dan ramai di media sosial. Mengingat pada masa kini penyebaran informasi apapun akan cepat tersebar karena kemudahan dari mengakses internet dan media sosial. Dalam beberapa modus dari kasus fetish, kebanyakan korban dimanipulasi oleh pelaku agar tanpa sadar menjadi objek pemuas fetish bagi pelaku. Berikut beberapa kasus mengenai fetish yang sempat ramai di media sosial beberapa waktu lalu di Indonesia, diantaranya yaitu:

1. Kasus Fetish Jarik Bungkus

Kasus ini mencuat dan menjadi perhatian publik setelah adanya pengguna media sosial Twitter pada bulan Juli 2020 bernama@m_f***is yang mengaku telah menjadi korban pelecehan seksual oleh pelaku yang berinisial G. Dalam pengakuannya tersebut ia mengaku telah diminta pelaku $G$ untuk mau badanya dibungkus dengan menggunakan kain jarik yang nantinya diikat menyerupai pocong.

Peristiwa tersebut bermula ketika pelaku $G$ yang tiba-tiba menghubungi korban melalui pesan secara online di Instagram. Didalamnya ia meminta korban untuk mau membantunya dalam melakukan suatu penelitian ilmiah untuk tugas akhir. Karena memang pelaku G sendiri mengaku sebagai mahasiswa tingkat akhir pada salah satu universitas dan sedang tahap menyusun tugas akhir, untuk itu ia meminta korban untuk membantunya dalam dalih penelitian/riset.

Didalamnya pelaku G juga menjelaskan kepada korban terkait seperti apa penelitiannya tersebut. Pelaku $G$ menjelaskan bahwa korban harus membungkus tubuhnya dengan kain jarik sampai menutupi seluruh badan layaknya jenazah. Dalam penelitian itu pelaku $G$ mengaku ingin melihat reaksi manusia ketika dalam keadaan terbungkus.

Awalnya korban menolak ajakan tersebut, namun pelaku $G$ terus meyakinkan dan memaksa korban untuk mau berpartisipasi dalam risetnya tersebut. Akhirnya karena pelaku G terus memohon kepada korban, akhirnya ia kemudian mau untuk membantu riset tersebut. Setelahnya, pelaku $G$ dan korban menentukan tempat dan hari untuk bertemu dan melakukan kegiatan bungkus-membungkus tersebut.

Setelah kejadian terebut, awalnya korban masih tidak tahu kegiatan yang telah dilakukannya merupakan suatu tindakan untuk memenuhi fetish pelaku. Korban mengetahui hal tersebut setelah ia menceritakan pengalaman yang dialaminya kepada temannya dan membaca artikel yang ada di internet bahwa hal tersebut merupakan salah satu penyimpangan seksual yaitu fetish.

Setelahnya kemudian korban menceritakan pengalamannya dan mengunggahnya di media sosial. Dalam postinngannya, korban juga menyertakan foto dan video saat ia dibunggkus dengan menggunakan kain jarik, tidak lupa dengan bukti percakapan antara korban dan pelaku $G$ (Suara.com, 20121).

\section{Kasus Fetish Mukena Berkedok Endors}

Peristiwa tidak menyenangkan menimpa pada sorang model asal malang yang kemudian menceritakan kejadian buruk yang menimpanya tersebut dan dibagikan pada akun @j j** ${ }^{* *}$ tz pada bulan Agustus 2021. Didalamnya ia mengaku sebagai korban pelecehan seksual dengan kedok kerja sama dengan online shop. 
Hal tersebut bermula ketika korban JH memenangkan sebuah ajang kontes kecantikan yang diikutinya. Dimana didalamnya toko mukena yang berinisial GM juga menjadi salah satu sponsor dari ajang kontes kecantikan tersebut. Kemudian sebagai pemenang, korban diminta untuk berfoto dengan menggunakan salah satu dari produk toko tersebut.

Dari situ korban lalu dihubungi oleh pemilik toko yang mengaku sebagai perempuan berinisial R. Setelah itu, R juga menawarkan pekerjaan untuk menjadi model foto katalog kepada korban. Namun setiap sesi pemotretan tiba, R tidak pernah datang ke lokasi, di likasi tersebut hanya ada fotografer dan seorang laki-laki berinisial DA yang mengaku sebagai adik dari R.

Selama sesi pemotretan berlangsung tidak ada kecurigaan yang dialami oleh korban. Awalnya juga hubungan antara korban JH dan pemilik toko R baik-baik saja. Hingga pada suatu ketika korban JH mendapati sebuah akun twitter yang mengunggah kumpulan foto orang menggunakan mukena namun lengkap dengan data diri modelnya. Jadi pemotretan yang selama ini dijalaninya bukan untuk suatu katalog melainkan untuk di upload pada akun twutter tersebut. Selain itu akun tersebut juga merujuk pada ujaran yang tidak senonoh, sehingga membuat korban JH banyak mendapat pesan yang tidak pantas dari pengguna sosial lainnya. Serta diketahui pula fakta bahwa pemilik toko yang bernama $R$ ebenarnya tidak pernah ada, hal itu karena pelaku DA memanipuasinya dengan mengaku menjadi $\mathrm{R}$.

Karena korban JH merasa telah dirugikan kemudian ia mengunggah pengalamannya pada media sosial, setelah itu diketahui pula terdapat korban lain yang berinisial AZK dan AM. Bersama korban lainnya kemudian ia bersama-sama melaporkan pelaku DA ke polisi.

Dari hasil pemeriksaan kepolisan dibantu dengan ahli bahasa dan psikolog, diketahui bahwa pelaku telah ngalami gangguan fetishisme seksual dengan objek mukena sejak kecil, lebih tepatnya pada kelas 4 sekolah dasar. Setelah itu, pelaku DA menyampaikan permintaan maaf saat kepolisian menggelar pers. Ia juga mengaku siap untuk diproses secara hukum apabila tindakannya tersebut telah melanggar hukum pidana. Pelaku DA juga menyanggupi untuk melakukan terapi terkait penyembuhan dari gangguan seksual yang telah dialaminya. Namun dari hasil pemeriksaan polisi menyebutkan bahwa tidak ada unsur pidana dalam perkara tersebut (Liputan6.com, 2017).

\section{Kasus Fetish Foto Mata Diperban}

Seorang warganet mengungkap adanya dugaan fetish terhadap wanita yang matanya diperban setelah dirinya hampir saja mnjadi korban dari pelaku tersebut. Pengalaman itupun dibagikannya melalui media sosial twitter @jxpxtcr pada 6 Agustus 2021 lalu.

Kejadian tersebut bermula saat beberapa hari sebelumnya korban membuat cuitan mengenai matanya yang sakit dan sedang diperban. Kemudian ada yang meresponnya dengan memberi pesan pribadi melalui DM dan menanyakan terkait kondisi matanya yang sakit sebelumnya. Selain itu pelaku juga meminta sejumlah foto korban yang matanya sedang diperban.

Awalnya korban tidak menaruh curiga aapun terhadap orang tersebut. Hingga kemudian pelaku mengikuti akun media sosial korban. Dari situ korban ingin mengikui balik akun pelaku namun sempat ditolak. Namun akhirnya akun pelaku dapat diikuti balik oleh korban. 
Selanjutnya beranda pada akun korban sudah dipenuhi dengan akun-akun yang tidak pantas dan dan beberapa foto sksi yang di retweet oleh pelaku. Curiga dengan pelaku kemudian korban membuka akun pelaku dan menemukan beberapa foto dari para korban yang lainnnya.

Setelah mengalami kejadian tersebut ia mencoba untuk menghubungi korban lainnya untuk mencoba mengkonfimasi tindakan pelaku. Setelah ada yang meresponnya kemudian ia segera membuat cuitan diakunnya. Hingga sekarang akun pelaku sudah tidak ditemukan lagi keberadaanya(metro.tempo.co, 2017).

\section{Kasus Fetish Kaos Kaki}

Seorang pengguna twitter dengan akun @ $\mathrm{d}^{* *} \mathrm{e}^{*}$ s membagikan pengalamannya ketika dipaksa untuk memenuhi fetish seseorang. Dalam unggahan tersebut korban menyebutkan bahwa ia berulangkali dipaksa untuk mengirim foto ketika sedang menggunakan kaos kaki. Korban berkata bahwasannya pelaku merupakan salah seorang kenalannya.

Sejak awal, permintaan dari pelaku sudah berulangkali ditolak oleh korban, namun pelaku berdalih bahwa foto kaos kaki yang ia minta hanya merupakan koleksi semata. Korban sering merasa terganggu hingga akhirnya korban memilih untuk memblokir nomor milik pelaku. Namun pelaku tidak jera, ia malah menghubungi adik korban untuk meminta foto kaos kakinya beserta segenggam tanah dihalamannya. Pelaku mengaku sedang terkena guna-guna dan meminta bantuan untuk menghilangkan dengan cara tersebut.

Setelah ditelusuri lebih lanjut, ternyata bukan hanya korban yang diminta hal serupa oleh pelaku. Namun korban tidak membawa kasus ini ke jalur hukum, korban hanya ingin si pelaku mendapatkan sanksi sosial dengan cara mengunggahnya dimedia sosial.

\section{Kasus Fetish Serbet Dapur}

Kasus ini hampir mirip dengan kasus fetish mukena yang menawari seorang model untuk di endors. Begitu juga dengan kasus fetish serbet ini, korban bernama aulia mengaku ditawari endors oleh pemilik akun bernama@tamaserbet di instagram. Korban sempat bingung dengan tawaran endors tersebut, kemudian korban menulusuri akun tersebut, namun hal yang mengejutkan didapati oleh korban dimana pada tampilan feed pelaku banyak memasang foto kepala yang terbungkus kain serbet dalam berbagai warna.

Kemudian korban menceritakan kisahnya di media sosial twitter dengan akun@senjatanuklir. Cuitan tersebut diunggah pada tanggal 4 oktober 2020 dan mengundang berbagai tanggapan dari pengguna media sosial tersebut (popbela.com, 2021).

\section{Konsep Kesehatan Mental}

Kesehatan Mental merupakan kondisi kejiwaan manusia yang bersifat harmonis, individu yang memiliki jiwa sehat apabila pikiran dan perasaannya juga sehat, dengan demikian orang yang memiliki kesehatan mental berarti memiliki suatu kecerdasan dalam intelektual,emosional dan spiritualnya. Seseorang bisa dikatakan mempunyai kesehatan mental yang baik adalah jika kondisi batin kita dalam keadaan tenang serta tentram, sehingga memungkinkan untuk bisa menikmati kehidupannya sehari-hari serta menghargai orang lain dilingkungan sekitar. Orang yang sehat mentalnya mampu menghadapi tantangan hidup serta membangun hubungan baik dengan orang 
lain, akan tetapi orang yang kurang sehat mentalnya akan mengalami gangguan dalam suasana hati, kurangnya kemampuan berpikir, juga kurang mengedalikan emosi yang akhirnya dapat mengarah kepada perilaku yang tidak baik.

Kesehatan Mental pertama kali dicetuskan oleh seorang tokoh islam yang bernama Zakariyya ar-Razi pada tahun $251 \mathrm{H}$. Razi adalah orang pertama yang menyatakan bahwa kondisi jasmani individu itu banyak terpengaruhi oleh kestabilan jiwa individu tersebut, dan kestabilan jiwa individu ditentukan oleh lingkungannya, dengan begitu dalam mempercepat proses kesembuhan pasien, harus dilakukan upaya dalam bentuk terapi fisik dan juga terapi non fisik, adapun terapi fisik seperti pengenalan aroma terapi dan relaksasi, dan terapi non fisik itu yang berkaitan dengan agama atau religiusitas (Aditiyawarman, 2010).

Pada umumnya orang awam beranggapan bahwa gangguan jiwa disebabkan oleh santet atau guna-guna. Akan tetapi sesungguhnya gangguan kesehatan mental disebabkan oleh banyak faktor, salah satunya adalah gangguan dari arah serta tujuan dari aktivitas seksual terhadap objek yang tidak semestinya guna memperoleh kepuasan dinamakan dengan penyimpangan seksual (Deviasi Seksual) (Syauqani, 2006).

Salah satu bentuk penyimpangan seksual adalah Fetishisme. Fetishisme dapat disertai dengan gangguan kesehatan mental, seperti ketika seseorang memiliki gangguan mood seperti halnya gangguan kecemasan maupun depresi. Namun menurut psikolog Inez Kristanti mengatakan bahwa Belum tentu Ketika seseorang yang memiliki dorongan seperti ini merealisasikan fetish-nya dengan pasangan yang memberikan persetujuan atau consent (mau sama mau), fetish bisa saja tidak menjadi sebuah masalah. Akan tetapi menjadi berbeda apabila kecenderungan ini dapat menimbulkan distress yang signifikan bagi seseorang yang mengalami fetish, hal itu dapat merugikan orang lain atau dapat memaksa orang lain melakukan fetish yang sebenarnya tidak diinginkan (Tirto.id, 2021).

\section{Terapi Penanggulangan Penyimpangan Seksual Fetish Pada Perilaku Transeksual}

Ada beberapa pendapat untuk penanggulangan penyimpangan seksual, antara lain:

1. Pendapat Abdullah Nasih Ulwan, penanggulagan penyimpangan seksual bisa dilaksanakan dengan melaksanakan Pendidikan seksual. Fase pertama, usia 7-10 tahun, disebut masa pra pubertas, dimana pada fase ini anak diberi pelajaran tentang etika meminta izin memandang sesuatu. Fase kedua, usia 10-14 tahun, pada fase ini anak dihindarkan dari berbagai bentuk rangsangan seksual. Fase ketiga, usia 14-16 tahun disebut masa baligh. Jika anak sudah siap menikah maka diberikan Pendidikan mengenai adab berhubungan seksual. Fase keempat, fase ini diberi pelajaran tentang tata cara menjaga diri dari perbuatan tercela, jika memang belum mampu melangsungkan pernikahan.

2. Pendapat Ali Akbar, menurut beliau cara penanggulangan penyimpangan seks adalah dengan menanamkan Pendidikan agama dan dengan pendididikan seks.

3. Pendapat M. Bukhori, menurut pendapat beliau penanggulangan penyimpangan seksual bisa dicegah dengan Pendidikan seks yang mencakup anatara lain adalah

a. Menganjurkan mereka untuk berpuasa agar bisa mengurangi syahwat 
b. Agar jangan dibiarkan bebas bergaul antara remaja putra dan remaja perempuan. Pergaulan yang bebas akan menimbulkan hawa nafsu birahi,

c. Untuk senantiasa menjaga aurat, sebab aurat adalah bagian tubuh Wanita yang cepat menimbulkan rangsangan seksual.

d. Memberikan pengertian dan penyuluhan terkait bahaya zina (Thanthowi, 2011).

Adapun bentuk terapi lain yang bisa digunakan untuk pelaku penyimpangan seksual adalah sebagai berikut:

1. Cara pengenalan diri serta tindak otoriter diri

Otak manusia itu didalamnya berbentuk susunan sel-sel yang terkoordinasi dengan sempurna sehingga dapat menghasilkan proses berpikir. Proses berpikir itulah yang dikenal dengan pikiran. Pikiran ini yang memutuskan segala sesuatunya. Selanjutnya didalam jiwa manusia ada yang Namanya Nurani, aturan yang hakiki, norma, naluri, keyakinan, suara hati adalah suatu bentuk pemberi pertimbangan kepada proses berfikir yang dilaksanakan oleh otak. Dengan menghasilkan suatu keputusan atau tidak.

Terapi ini dilakukan cara dengan mencoba membuang jauh pikiran-pikiran yang berhubungan dengan transeksual apalagi sampai pada perilaku waria. Apabila masih terasa sulot dan tidak mampu maka cobalah untuk berfikir selain hal tersebut. Dengan beristighfar atau mengucap takbir berkali-kali. Lakukan hal tersebut ketika hendak tidur atau ketika melamun.

\section{Terapi Sugesti}

Dengan mencoba mengucap lirih atau dalam hati (sugesti) kalimat-kalimat berikut, seperti: "Transeksual menjïikan, transeksual sesat, aku bukan pelaku transeksual, aku manusia normal." Dengan mengucapkan kalimat itu berkali kali sambil membayangkan apa yang dia ucapkan, kemudian pikiran liar itu akan melawan dengan bentuk kebosanan. Terus mengatakan itu seperti orang sedang melakukan wirid dengan khusuk. Diucapkan minimal 2.000 kalimat dalam satu hari. Jika diperlukan ditulis sehari lima puluh ketas HVS bolak balik. Hal tersebut bisa dilakukan saat melamun, sendirian, bingung, saat sebelum tidur atau hingga bangun tidur.

3. Kepasrahan dalam Doa

Dengan berpasrah dan memohon kepada Allah bahwa kita adalah hamba yang tidak memiliki apapun selain harapan, dengan menyatukan jari jemari, tekuk lutut memohon kepada-Nya, menundukkan kepala dan ungkapkan apa yang menjadi kendala dalam hati. Cara ini adakah cara dalam usaha pendekatan spiritual yakni dengan memohon ampun dari Allah SWT.

Selain ditinjau dari pandangan psikologi Pendidikan sebagai solusi, terapi bisa ditinjau juga dari aspek syari'at Islam, yakni dengan cara:

1. Penanaman keimanan atau aqidah yang kuat

Dalam Islam, ada eenam keyakinan yang harus ditanamkan kepada manusia, yakni: a) Iman kepada Allah, b) Iman kepada Malaikat-malaikat Allah, c) Iman kepada Kitab-kitab Allah, d) Iman kepada Rasul-rasul Allah, e) Iman kepada Hari Akhir, f) Iman kepada Qadha dan Qadar Allah. 
2. Menjaga rutinitas ibadah

Dimulai dari ibadah yang wajib seperti sholat lima waktu, puasa di bulan Ramadhan, zakat dan juga haji sampai ibadah yang bersifat sunnah seperti sedekah, serta sholat sunnah. Ibadah pokok ini adalah berkaitan langsung dengan proses penanaman keyakinan sebagai bagian dari spiritualisme jiwa manusia.

3. Memperbaiki sikap atau akhlak

Sikap atau akhlak yang dimaksud adalah mulai dari menghindari hal-hal yang sifatnya dilarang dalam syari'at Islam maupun hukum publik hingga melaksanakan hal-hal yang diperintahkan atau hanya sekedar perbuatan yang memiliki keutamaan jika dilakukan.

Perbuatan yang dilarang dalam hukum Islam dan juga publik meliputi membunuh, mencuri, minum minuman keras, berzina, menipu dan lain sebagainya yang hanya bisa merusak diri dan juga orang lain. Perbuatan yang termasuk terpuji dalam hukum Islam dan publik diantaranya jujur, baik hati, penolong, penyayang, rendah hati, serta segala perbuatan yang bermanfaat untuk diri sendiri, orang lain dan lingkungan sekitar (Suteja, 2015).

Kepada pelaku deviasi seksual seperti lesbi, gay, dan sebagainya, dan juga terhadap pelaku penyimpangan perilaku, contohnya waria atau sejenisnya, tindakan hukum di dalam agama Islam sangat tegas dan keras. Tindakan hukum seperti itu harus dilaksanakan dikarenakan sesungguhnya mereka sangat jelas sudah melakukan penyimpangan atau deviasi perilaku dan seksual. Penyimpangan perilaku dan seksual ini tidak dapat dianggap sebagai hak asasi manusia. Dengan dalih berlindung dibalik hak asasi manusia, tidak diperbolehkan penyimpangan seperti itu dipelihara, dikarenakan penyimpangan seperti itu bisa merusak kehidupan serta generasi manusia, termasuk diri dari pelaku itu sendiri. Seseorang yang melakukannya berarti sudah menyimpang seksnya. Dan orang yang sudah menyimpang seksnya maka mengalami penyakit secara kejiwaan.

Allah berfirman dalam Al-Qur'an Surat Al- A'raf pada ayat 81 yang artinya: "Sesungguhnya kamu mendatangi laki-laki untuk melepaskan nafasmu (kepadamereka), bukan kepada wanita, malah kamu ini adalah kaum yang melampaui batas". Dalam Riwayat Abu al-Dunya, kaum Nabi Luth menggauli anus kaum perempuan, lalu pindah dilakukan kepada kaum pria atau melampiaskan nafsu seksnya kepada kaum pria. Dalam hal tersebut semua ulama sepakat tentang keharaman perbuatan homoseksual atau lesbian, pelakunya sangatlah dikutuk oleh Agama Islam dan salah satu yang termasuk kedalam dosa besar. Dan bahkan perilaku tersebut bisa digolongkan sebagai tindak pindana jarimah. Kemudian dalam surat Al-Mu'minun ayat 5-6 dijelaskan yang srtinya: 'Dan orangorang yang menjaga kemaluannya, Kecuali terhadap istri-istri mereka atau budak yang mereka miliki, maka sesunggubnya mereka dalam bal ini tiada tercela".

Oleh karena itu, berkaitan dengan usaha menjaga kehidupan dan juga generasi mendatang, maka dari itu penyaluran seksual yang diperbolehkan oleh syari'at agama Islam hanya dengan istri yang telah mereka nikahi. Jika memang tidak mampu untuk bisa menahan nafsu serta syahwatnya maka di wajibkan bagi mereka untuk menikah. Dikarenakan perbuatan zina sangat diharamkan dalam syari'at, agar bisa terhindar dari perbuatan zina tersebut alangkah baiknya segera menikah. 


\section{Kesimpulan}

Perilaku penyimpangan seksual memiliki banyak jenis, salah satunya yaitu Fetishisme. Fetishisme adalah bentuk penyimpangan seksual dengan menggunakan benda seks seperti pakaian dalam, sepatu, kaos kaki, atau lainnya guna mencapai kepuasan seksualnya Perilaku penyimpangan seksual atau deviasi seksual yang terjadi tidak begitu saja melainkan terjadi karena beberapa faktor diantaranya diantaranya adalah lingkungan yang kurang baik, pernah menjadi korban, libido yang tidak terkontrol, dan juga pengaruh alcohol. Penyimpangan seksual tersebut menjadi gangguan jika mengganggu yang bersangkutan dalam melakukan kegiatan sehari-hari, gangguan tersebut biasa berupa stress, menghambat hubungannya dengan orang disekitar, mengganggu dan juga membahayakan orang lain. Dengan adanya gejala berupa stress dan lainnya akan mengganggu serta mempengaruhi kesehatan mental. Adapun penanggulangan serta terapi yang diberikan berupa pendidikan seks, tidak otoriter dengan diri, sugesti, serta kepasrahan dalam doa.

\section{Ucapan Terima Kasih}

Dalam kesempatan yang baik ini perkenankanlah para penulis menyampaikan rasa syukur kehadirat Allah SWT atas pertolongan-Nya para penulis bisa menyelesaikan penelitian ini dengan baik dan tak lupa penulis mengirimkan sholawat dan salam kepada Nabi agung Muhammad SAW yang telah menunjukkan umat Islam kepada jalan kebenaran. Ucapan terima kasih juga penulis sampaikan kepada: 1) Tuhan Yang Maha Esa, 2) Orang tua para penulis yang selalu memberikan semangat dan motivasi, 3) Ibu dosen yang telah meluangkan waktunya disela-sela kesibukannya untuk memberikan petunjuk, arahan, serta saran dari awal hingga akhir penulisan., 4) Sahabatsahabat dan teman-teman yang sudah membantu penulis dan berbagi motivasi dan dukungan. Akhirnya kepada Allah SWT para penulis berharap semoga segala pengorbanan dan segala sesuatunya yang sudah dengan tulus serta ikhlas yang telah diberikan para penulis akan selalu mendapatkan limpahan rahmat dan karunia-Nya.

\section{Referensi}

Abidin, A. A. (2017). Perilaku Penyimpangan Seksual dan Upaya Pencegahannya di Kabupaten Jombang. PROSIDING, 1(7), 545-563.

Abidin, A. A., \& Luthfi, M. (2016). Urgensi Pendidikan Seks Pada Siswa Madrasah Ibtidaiyah Dalam Upaya Pencegahan Perilaku Penyimpangan Seksual Di Kabupaten Jombang. JURN AL ILMLAH DID AKTIKA: Media Imiah Pendidikan dan Pengajaran, 17(1), $18-37$.

Aditiyawarman, I. (2010). Sejarah Perkembangan Gerakan Kesehatan Mental. Komunika: Jurnal Dakwah Dan Komunikasi, 4(1), 91-110.

Alimi, Y. (2004). Dekonstruksi Seksualitas Poskolonal, Yogyakarta: LKIS

Anggito, A \& Setiawan, J (2018). Metodologi Penelitian Kualitatif. Sukabumi: CV Jejak

Annur, I. (2012). Tinjauan Kriminologis dan Hukum Islam terhadap Deviasi Seks Dalam Hal Kejahatan Seksual (Skripsi, Universitas Islam Negeri Alauddin Makassar).

Fakhriyani, D. V. (2017). Kesehatan Mental. Pamekasan: Duta Media Publishing 
Fatima, S. (2019). Sistem Pakar Diagnosa Penyakit Mental yang Memicu Psikopat Dengan Menggunakan Metode Forward Chaining. Kumpulan Karya Ilmiah Mahasiswa Fakultas sains dan Tekbnologi, 1(1), 36-36.

Hidayat, A. A \& Uliyah, M. (2015). Buku ajar kebutuhan dasar manusia". Surabaya: Healt Books Publishing

Jauhari, A. T. (2011). Konsep Kartini Kartono dalam penanggulangan penyimpangan seks bagi remaja dalam perspektif pendidikan Islam (Skripsi, IAIN Walisongo).

Junaedi, D. (2016). Penyimpangan seksual yang dilarang Al-qur'an. Jakarta: PT Elex Media Komputindo.

Martiasari, A. (2019). Kajian Tentang Perilaku Kejahatan Dan Penyimpangan Seksual Dalam Sudut Pandang Sosiologis Dan Hukum Positif Indonesia. Yurispruden: Jurnal Fakultas Hukum Universitas Islam Malang, 2(1), 103-118.

Setyatmoko, P. F., \& Supriyanto, T. (2017). Penyimpangan Sosial dalam Novel Neraka Dunia Karya Nur Sutan Iskandar. Seloka: Jurnal Pendidikan Bahasa dan Sastra Indonesia, 6(3), 307-313.

Sukoco, H. Z., Althof, F., \& Nihayah, U. (2021). Menyoal Gangguan Kesehatan Mental Deviasi Seksual Fetish. Islamic Counseling: Jurnal Bimbingan dan Konseling Islam, 5(2), 148-164.

Suteja, J. (2016). Model Terapi Terhadap Perilaku Penyimpangan Transeksual dalam Tinjauan Islam dan Psikologi Pendidikan. Edueksos: Jurnal Pendidikan Sosial \& Ekonomi, 4(1).

Syafi'i, I. (2014). TA: Rancang Bangun Sistem Pakar Diagnosis Gangguan Preferensi Seksual Menggunakan Metode Certainty Factor pada Institusi Kepolisian (Skripsi, Institut Bisnis dan Informatika Stikom Surabaya).

Syauqani, S. (2006). Pornografi dan Pornoaksi: Perspektif Agama dan Kesehatan Mental. Ulumuna, 10(2), 285-302.

Wardhani, T. Z. Y \& Krisnani, H. (2020). Optimalisasi peran pengawasan orang tua dalam pelaksanaan sekolah online di masa pandemic covid-19", Prosiding Penelitian \& Pengabdian Masyarakat, 7(1).

Yandri, H., Juliawati, D., \& Rusliah, N. (2020, October). Analisis stres masyarakat Kerinci ditinjau dari intensitas akses informasi pandemi COVID-19 (Stress Analysis of Kerinci Community in Terms of Access Information Intensity of COVID-19 Pandemic). In National Conference on Psychosmart.

\section{Sumber Internet}

https://nasional.kompas.com/read/2021/09/06/10561441/perjalanan-kasus-saipul-jamil-daripencabulan-terhadap-anak-penyuapan?page $=$ all , diakses pada 06 November 2021

https://news.detik.com/berita/d-5722487/sorotan-komnas-perempuan-soal-kasuspenyimpangan-seks-dokter-di-semarang diakses pada 06 November 2021

https://tirto.id/penjelasan-psikolog-soal-fetish-dan-kasus-gilang-bungkus-kain-jarik-fUP9 diakses pada 27 Oktober 2021

https://www.google.com/amp/s/m.liputan6.com/amp/4663338/pemeriksaan-psikologterlapor-sudah-fetish-mukena-sejak-sekolah-dasar diakses pada 27 Oktober 2021

https://www.google.com/amp/s/metro.tempo.co/amp/1493087/viral-fetish-meminta-fotoperempuan-dengan-diperban-ini-kata-korban , Diakses pada 27 oktober 2021 
https://www.google.com/amp/s/www.popbela.com/relationship/sex/amp/estisetiyowati/kasus-fetish-seksual-viral-di-media-sosial diakses pada tanggal 6 November 2021

https://www.google.com/amp/s/yoursay.suara.com/amp/news/2021/08/23/121606/4-kasusfetish-yang-pernah-gegerkan-jagat-maya-indonesia diakses pada 27 Oktober 2021 